DOI: 10.1590/1809-4503201500050011

ORIGINAL ARTICLE / ARTIGO ORIGINAL

\title{
The invisibility of heterosexuality in HIV/AIDS prevention for men
}

\author{
A invisibilidade da heterossexualidade na prevenção do HIV / AIIDs entre homens
}

Andréa Fachel Leal', Daniela Riva Knauth', Márcia Thereza Couto"

ABSTRACT: Heterosexual men have been a forgotten group for HIV/AIDS interventions and research. Our goal was to identify the different elements that interfere in the prevention of HIV/AIDS among heterosexual men, covering both traditional methods of prevention (especially safe sex practices and testing) and new strategies for prevention (pre- and post-sexual exposure prophylaxis, prevention treatment, and circumcision) in this population. This exploratory article consists of a nonsystematic review of the literature. We discuss the invisibility of heterosexual men in policies, in programs, and in health services. The several interventions analyzed are still poorly monitored and evaluated, so there is a lack of consistent evidence regarding the impact of prevention strategies in this population. Different masculinities, including hegemonic conceptions of masculinity, must be the foundation for interventions targeting men. Men must not be seen merely as a "bridge" in the spread of the HIV/AIDS epidemic, but also as victims of gender patterns that make them vulnerable.

Keywords: Men. Masculinity. Heterosexuality. Acquired immunodeficiency syndrome. Gender identity. Review.

'Graduate Program in Epidemiology, Universidade Federal do Rio Grande do Sul - Porto Alegre (RS), Brazil

"Graduate Program in Preventive Medicine, Universidade de São Paulo - São Paulo (SP), Brazil.

Corresponding author: Andréa Fachel Leal. Universidade Federal do Rio Grande do Sul. Instituto de Filosofia e Ciências Humanas, Departamento de Sociologia. Avenida Bento Gonçalves, 9500, prédio 43311, sala 106 A1, CEP: 91509-900, Porto Alegre, RS, Brasil. E-mail: fachel.leal@ufrgs.br

Conflict of interests: nothing to declare - Financial support: none. 
RESUMO: Os homens heterossexuais têm sido um grupo esquecido nas intervenções e pesquisas sobre HIV/ AIDS. Nosso objetivo foi identificar os diferentes elementos que interferem na prevenção do HIV/AIDS entre homens heterossexuais, contemplando tanto os métodos de prevenção tradicionais (especialmente as práticas de sexo seguro e o teste anti-HIV), como elementos para pensar o uso das novas estratégias de prevenção (profilaxia pré e pós-exposição sexual, tratamento para prevenção e circuncisão) nessa população. O artigo apresenta uma revisão narrativa da literatura. Pontuamos a invisibilidade dos homens heterossexuais, tanto na esfera de políticas e programas quanto nos serviços de saúde. As diferentes intervenções analisadas ainda são pouco monitoradas e avaliadas, de modo que há uma carência de evidências consistentes para pensarmos sobre o impacto das estratégias de prevenção nessa população. As diferentes masculinidades, incluindo suas concepções hegemônicas, devem embasar intervenções para homens, que não são apenas uma "ponte" para a disseminação da epidemia, mas também vítimas desta e dos padrões de gênero.

Palavras-chave: Homens. Masculinidade. Heterossexualidade. Síndrome de imunodeficiência adquirida. Identidade de gênero. Revisão.

\section{INTRODUCTION}

The academic production on men regarding health-illness issues emerged in the late 1970s in the United States, focusing primarily on health deficits in male segments. At that time, an important paradox had to be dealt with: while men held more power than women, they had disadvantages compared to the latter with regard to morbidity and mortality rates ${ }^{1}$. In the following decade, research focused on the influence of the social construction of masculinity in the production of health risk behaviors and on the difficulties in finding care ${ }^{2}$. The presence of heterosexual men as subjects of studies came late in the research and intervention protocols, and was finally covered in studies on reproductive and sexual health, historically aimed at women ${ }^{3}$, starting from the 1990s. Since 2000, a diversification of research has been observed in terms of empirical objects and efforts in analytical advancement, as other references (class, race/ethnicity, generation, etc.) began to be incorporated by gender studies, because of their relevant role as social markers that impact the construction and experiences of masculinity ${ }^{4}$.

In line with the development of more general literature on the relationship between gender and health in the field of HIV/AIDS studies, the centrality of gender issues regarding vulnerability to HIV, as well as for the prevention of AIDS and other sexually transmitted diseases (STDs), is recognized ${ }^{5,6}$. In general, it is understood that the recognition of the need and the decision to adopt preventive measures against HIV are influenced by the way that the relationships between men and women are configured socially and culturally, and by how masculinities and femininities are designed and affirmed within the affective and sexual relations ${ }^{7-9}$. 
And despite the centrality of the male condom in strategies to prevent HIV / AIDS, little progress has been made in order to reflect how this strategy impacts the different groups of men, either in terms of their sexual orientation (hetero or homosexual), or in regard to differences in social, racial, age and generational belonging existing between men. Thus, considering prevention strategies for HIV/AIDS among men implies discussing masculinities in the plural. That is, discussing that different men also occupy different positions in the social structure, where there are gender relations. Masculinities not only are multiple, but are related to each other hierarchically; hence the term "hegemonic masculinity," ${ }^{10}$ which is defined by two essential elements: the finding of a plurality of masculinities and of a hierarchy of masculinities.

Hegemonic masculinity is distinguished from other masculinities as the idealized and normative way of being a man, the one that is the standard of being a man, in relation to which other men are positioned, in a certain society and historical moment ${ }^{11}$. Hegemonic masculinity is not said to be a standard, or dominant, because of its frequency: only a minority of men are able to experience it. In Brazil, currently, although it may be difficult to say there is only one model of masculinity, it can be said that there is a pattern of hegemonic masculinity that is personified in heterosexual white men who are sexually active, have high income and higher education, as well as healthy and strong bodies.

The ways that men have to experience and to demonstrate their masculinity - and to position themselves within a spectrum that has hegemonic masculinity on its top makes them vulnerable to different problems and conditions relating to their health. For example, bearing pain, being strong, having a dominant and even aggressive behavior, not showing fear or greater concern for their own safety are some practices associated with masculinity ${ }^{2}$. In health, the concept of hegemonic masculinity has been used in studies of violence (including violence against women ${ }^{12}$, sexual violence ${ }^{13}$, and suicide $\left.^{14-16}\right)$, on access and use of health services ${ }^{17,18}$, and on sexual health ${ }^{19}$.

The expressions of hegemonic masculinity in the field of sexuality, such as the requirement of multiple sexual partners, the perception of invulnerability to HIV and other STDs, the affirmation of heterosexuality, consumption of alcohol, among others, end up exposing men to STDs and HIV / AIDS. In addition, the large percentage of HIV infections in heterosexual relationships, affecting not only men but also women, indicates that the control of the AIDS epidemic necessarily involves the inclusion of heterosexual men in prevention strategies. However, the literature tends not to focus on males as especially vulnerable.

Despite the recognition that the symbolic and practical dimensions of the exercise of masculinities have impacted the perception and risk management of heterosexual men toward HIV / AIDS (because they promote an increase in their vulnerability to these risk sexual practices, due to either the number of partners or the identification of a pseudo self-protection and the idea of masculinity associated with virility, among others $)^{20,21}$, it is important to question why this group is still overlooked in studies on this 
epidemic and, even more, almost excluded from intervention programs ${ }^{6,19}$. For example, in Brazil, only in 2009 a specific policy, the National Policy for Integral Attention to Men's Health (PNAISH), addressed to the male population was launched ${ }^{22}$. Its recent character indicates, in a way, that men were subsumed in the general population, not deserving emphasis in public health policies.

In face of this, the present study aimed to identify, through the narrative review of literature, the different elements that interfere with prevention of HIV/AIDS among heterosexual men, both covering traditional methods of prevention (condoms, safe sex practices, and anti-HIV test) and surveying elements to come up with new strategies for prevention (pre- and post-sexual exposure prophylaxis, treatment, and circumcision) for this population.

\section{METHODS}

To support the reflection developed in this study, we conducted a narrative review of the literature on the subject. The review of literature was performed on the major health databases, through Portal Periódicos Capes, contemplating MEDLINE, SciELO and PubMed, among others available on the Internet. The following terms were used in the search: prevention AND HIV, men; AND heterosexual, HIV; AND heterosexual, male circumcision; AND HIV, testing; AND HIV, prison; AND men, truck drivers AND HIV; AND elderly men AND HIV. From the reading of the titles and abstracts, articles were selected for reading in full. The articles dealing exclusively with clinical questions and biological markers were excluded from the analysis. We included 66 articles that addressed behavioral aspects of heterosexual men, interventions for the prevention of HIV / AIDS in this segment of the population, and reviews of literature on the topic.

To contemplate the perspective of public health policies aimed at the male segment of the population in Brazil, we also analyzed the document presenting the proposal of $\mathrm{PNAISH}^{22}$. The analysis was also complemented by reading the Plan for Fighting AIDS Epidemic and STDs among gay men, men who have sex with men (MSM) and transvestites ${ }^{23}$, and the Brazilian Program for Attention to Indigenous Health on HIV/ AIDS and other STDs ${ }^{24}$.

\section{RESULTS AND DISCUSSION}

The literature on HIV/AIDS prevention in heterosexual men is very limited. Heterosexual men are subsumed in the so-called "general population," drug users, and, indirectly, in interventions aimed at women; eventually, they are included in studies that focus on traditionally "male" occupations, such as truck driving or the military ${ }^{25-27}$. 
Authors dedicated to the theme draw attention to how this has been a forgotten group in interventions and research on HIV/ $\operatorname{AIDS}^{28}$.

\section{MEN IN HEALTH POLICIES AND SERVICES}

While homosexual men have occupied a position in the political and academic scene of studies on HIV/AIDS since the late 1980s, due to the impact of the first cases of the then-emerging epidemic and due to the role of social movements ${ }^{29}$, heterosexuals had little political protagonism and have long been, in the field of sexual and reproductive health, regarded as mere facilitators or as hindering the reproductive decisions of women $^{30}$, who were then the preferred target of studies and interventions. This prioritization in studies and interventions aimed toward homosexuals and women is undoubtedly associated with the role of gay and feminist social movements. From this perspective, heterosexual men are treated as an obstacle to HIV/AIDS prevention, whether by not assuming their sexual relations with other men or by not accepting to use condoms in their sexual relations, particularly with stable partners. At best, these studies consider that it would be necessary to better understand the values that guide their sexual and preventive behaviors as a way to help protect women ${ }^{31}$.

One of the factors listed in the search for answers on the late inclusion of heterosexual men in studies on HIV / AIDS is the fact that the exercise of male heterosexuality was, and remains, often linked to non-health-care and careless behavior in relation to himself, and especially toward women ${ }^{9,32,33}$.

As, originally, incorporation of gender in public policy is credited to feminism, which fights the asymmetry and inequality between men and women, men tend to be taken as a practically homogeneous "other" aimed at maintaining power and privileges that their gender enables ${ }^{4}$. In the same direction, both the scientific literature and health policies tend to promote a vision of the "generic man", which does not contemplate the multitude of possible masculinities or their relationships.

Thus, although PNAISH ${ }^{22}$ has recently presented the need to visualize and accommodate the diversity of men in the context of health care, we cannot ignore that, in the eyes of health policies formulated under a gender perspective, the current and dominant model of masculinity (heterosexual) still takes a central position, which has hindered the recognition of multiple masculinities and their interconnections with the vulnerability at three levels: individual, social, and programmatic ${ }^{34}$.

When heterosexual male audience is taken as a reference, as well as the way they are currently treated by PNAISH, there are various difficulties in the way of the fight against the HIV/AIDS epidemic. The first and decisive one is related to the low incorporation of the HIV/AIDS issue in the policy ${ }^{22}$, even though it appears as one of its objectives (paragraph 4, X). Thus, even if the fields of reproductive and sexual health are considered, if the indication of a direct dialogue with women's national health policy 
is exalted and, finally, if the purpose of anchoring the actions of the policy on Primary Care is a key principle, PNAISH does not prioritize the prevention of STDs, including $\mathrm{HIV} / \mathrm{AIDS}^{35}$.

The second difficulty of addressing men and HIV/AIDS refers to the very inclusion of men in health services, especially at the primary level of care, in terms of its little presence and its quality. The literature on the subject has indicated that this insertion faces barriers created by the cultural characteristics of the construction of masculinities that shape the ways in which men deal with health ${ }^{2}$; by the work of health professionals who (re)produce gender concepts, such as the idea that the male body is a locus of noncare ${ }^{36}$; and by the structure of health services in which we can identify a trend of not considering men as health intervention targets (as users who find it difficult to access services or to be welcomed with their demands and as potential subjects of care $\left.^{37,38}\right)$.

\section{TRADITIONAL METHODS FOR PREVENTION OF HIV/AIDS AMONG MEN}

Globally, there are few publications on interventions with heterosexual men m $^{39,40}$ aimed at preventing HIV/AIDS. Although the prevention and treatment for HIV/ AIDS in women are grounded in a heteronormative discourse ${ }^{41}$, in which prevail the conceptions of (vaginal) sex between men and women in monogamous relationships that can result in reproduction, with men, the discourse is not focused on heteronormativity. Prevention and treatment discourses for men are focused on same-sex sexual practices and the drug use (and abuse), especially through injection. The focus of the prevention propositions regarding women is on behavioral change - encouraging the adoption of condoms (male) in (hetero)sexual relationships — and the speech focused on men centers on not sharing needles/syringes during the use of intravenous drugs, as well as encouragement of safe $\operatorname{sex}^{42,43}$. In this sense, the female-male heterosexual transmission is virtually disregarded, increasing the invisibility of these factors in the context of the epidemic.

A systematic review of interventions aimed at heterosexual men with low- and middle-income identified 19 studies that sought to evaluate such interventions ${ }^{39}$. The authors conclude that the little existing literature shows that heterosexual men remain underrepresented in HIV prevention. The interventions studied involved unique individual sessions lasting $15 \mathrm{~min}$ to interventions of up to 13 sessions conducted by peers (exclusively for men or for men and women). Of the 19 interventions, 7 were based on IMB (Information-Motivation-Behavior Skills) principles (including 2 that were also models in behavioral or sociocognitive theories) and 5 in peer education principles (also including 2 IEC (Information-Education-Communication)). Of these 19 interventions, 9 were considered as successful regarding condom use; 
the positive effect seems to be associated with individual counseling strategies based on the principles of IMB. One of the interventions reviewed (individual counseling) was developed in Brazil ${ }^{44}$. Large-scale interventions were associated with long-term changes in relation to casual sex.

In Brazil, in terms of prevention actions, we can highlight the provision of inputs: the free distribution of condoms and lubricant gel, on a larger scale, as well as the female condom, to a lesser extent, by public health services and civil society organizations $^{45}$. Interventions aimed at the general public, such as mass campaigns organized on specific dates by the Brazilian Ministry of Health (Carnival, Valentine's Day, and World AIDS Day) or in certain places (motels and nightclubs), involve wide distribution of condoms.

Action planning by the Brazilian Ministry of Health for specific populations in Brazil, formalized in policies or programs, involve MSM and transvestites ${ }^{23}$, women ${ }^{46}$, and indigenous people ${ }^{24}$. Therefore, the only planning that involves heterosexual men, although not specifically designed as such, is the one with the indigenous population. The Progress Report of the Brazilian Response to HIV/AIDS $(2010-2011)^{45}$ refers to prevention actions that focus a mostly male, heterosexual audience with young recruits, military school and training center students and, among the military, people on peacekeeping missions. Such actions are described as education for peers, being the result of a partnership established in 2004 between the Brazilian Ministry of Health and the Brazilian Ministry of Defense. Interventions aiming at an eminently masculine and heterosexual public to a lesser extent, undertaken by non-governmental organizations with technical and financial support from federal, state, or local instances, were carried out among truck drivers ${ }^{27}$ and the elderly ${ }^{47}$.

The counseling and testing for HIV has been one of the prevention strategies widely used throughout the world, particularly from the expansion of access to antiretroviral therapy. Early diagnosis, in addition to allowing increased survival, exerts an impact also on the transmissibility of the virus ${ }^{48}$. And, despite being an old strategy (implemented since $1985^{49}$ ), with the anti-HIV test being offered for free in most of the countries, little is known about its impact in changing people's behavior, and about the circumstances that determine the test demand or about specific groups seeking the test. Global data indicate that only a portion of the population infected by the virus has knowledge of their HIV status ${ }^{50}$.

In Brazil, the data analysis of a population-based survey on sexual behavior ${ }^{51} \mathrm{com}$ paring the data collected in 1998 and 2005 showed that there was an increase in the number of people who underwent HIV testing from $20.2 \%$ to $33.6 \%$. However, if we only consider voluntary testing (excluding blood donations and testing during prenatal care), there were only $13.5 \%$ of the respondents in 1998 and $20.8 \%$ in 2005 who took the test. Among men, the youngest (16-19 years) and oldest (55 - 65 years), with less education and lower income, were those who the least underwent the test. 
The 2005 data indicate that heterosexual men, with no STDs and no children, had lower rates of testing. And as for women, prenatal care was the main reason for testing; men knew their HIV status through blood donation.

The available literature provides little data to allow understanding of how heterosexual men behave in relation to HIV counseling and testing. A few studies that analyze the testing by gender indicate that women are tested more than men $^{52}$, which is expected due to the strong recommendation of testing during prenatal care as a way to prevent vertical transmission of the virus. One review of literature on the subject $^{52}$ points out that the impact of testing and counseling, by increasing condom use among heterosexuals (not specifying the gender), occurs primarily in relation to eventual partners, but has little impact on regular partners. In addition, some studies $^{52}$ indicate that the impact is greater among serodiscordant couples and for the seropositive partner, without impact on the seronegative partner. As to obstacles performing the test, the studies analyzed refer to particularly the fear of a positive result, and the fear of the stigma associated with disease's and its impact on social relations ${ }^{9,49}$. Risk perception and, above all, previous experience with testing are other factors that motivate testing.

Data from the Survey on Knowledge, Attitudes and Practices related to STD and AIDS in the Brazilian Population aged 15-64 years (PCAP-2008) corroborate these findings, showing that testing for HIV is higher among women $(45.6 \%)$ than men $(27.2 \%)^{53}$. Although men, according to this study, have a higher frequency of sexual encounters, a higher number of casual partners, and a higher number of extramarital affairs, they also report greater condom use, particularly with eventual partners. In this analysis, however, the identity or sexual practices of men were not considered.

\section{NEW PREVENTION SCENARIOS}

Male circumcision is presented as an effective prevention method for HIV/AIDS from the dissemination of the results of two randomized clinical trials in African countries, which are added to other studies that already indicated the protective effect of circumcision for HIV/AIDS ${ }^{54}$. The editorial in The Lancet issue in which these clinical trials were published termed the findings about circumcision as a "new era" for HIV prevention ${ }^{55}$. This new era is characterized by measures supported by solid scientific evidence that can and should be implemented on a large scale in the male population in general.

The effectiveness of circumcision as an HIV prevention strategy was evaluated by a meta-analysis ${ }^{56}$. Despite the intervention being considered effective in reducing the transmission of the virus, authors pointed to the fact that the impact of this intervention on male behavior was not yet evaluated as most studies evaluate the short-term 
results. Some data suggest that circumcised men tend to feel extremely protected from STDs, and that this feeling of protection produces the desire to increase the number of sexual partners, as indicated by the projections of the study conducted in Uganda ${ }^{56,57}$. Thus, although the method has been found to be effective in reducing transmission of the virus, the behavioral impact of circumcision can neutralize the benefits obtained.

Another feature of the new era highlighted by the editorial in The Lancet ${ }^{55}$ is the medicalization of prevention, with the use of antiretrovirals pre- and post-sexual exposure prophylaxis (PrEP and PEP). Despite this initial euphoria with the new prevention strategies, the editorial of the magazine and further studies on these prevention strategies emphasize that new approaches should be combined with traditional strategies used for HIV/AIDS prevention, especially with the use of condoms. Regarding PrEP and PEP, the impact of gender patterns in the effectiveness of these new technologies has not been established. That is, how gender inequalities can affect the effectiveness of these interventions is a question still unanswered in the scientific literature ${ }^{58}$.

Although studies on PrEP contemplate heterosexual men, most of these focus on serodiscordant couples for HIV and in a stable relationship. As indicated in a qualitative study conducted in conjunction with a clinical trial (Partner PrEP Study) ${ }^{58}$, factors concerning the marital relationship are highlighted in the analysis of the results, particularly those relating to adherence. This study indicates that the stability of the relationship contributes to good adherence to PrEP, which is perceived as a means of preserving the relationship and the health of the HIV-negative partner. Furthermore, the authors acknowledge that these findings cannot be generalized due to the specific context of the studied population and the development of the study, with various interventions in this sense.

There is no scientific evidence on the impact of PrEP on the behavior of heterosexual men. Some studies ${ }^{58-60}$ on this new strategy indicate that there is a preference for PrEP in relation to condom use, due to the negative reasons, such as decreased sexual pleasure, associated with condoms. This finding may indicate a decrease in condom use among individuals who use PrEP, particularly men. The increase of condom use among the couples participating in the study protocols ${ }^{60}$ may be due to various interventions used during the study.

The compensation of the sexual risk among users of PrEP was explored in clinical trials. This compensation is not a specific issue of PrEP, but of all biomedical prevention strategies, such as circumcision and treatment of HIV-positive people for prevention ${ }^{59,60}$. One of the difficulties to assess gender issues is that most of the studies do not provide data separated by sex. So, even when it comes to adherence or condom use, it is not possible to identify whether both sexes have similar or different behaviors. 


\section{FINAL CONSIDERATIONS}

Thought for a long time as a "bridge" to female infection, and as having acquired HIV through other practices such as sex with men or drug use, heterosexual men were forgotten both by interventions and by scientific production on HIV/AIDS. The invisibility of heterosexual men and diversity in this segment of the population in all the studies on HIV / AIDS is largely because in the course of the epidemic over the past decades, these were perceived as active HIV transmitters but not as active agents in prevention ${ }^{31}$.

This results in the lack of consistent evidence to allow insight on the impact of the limited prevention strategies in this population. The few studies available indicate that interventions based on individual counseling can increase condom use, whereas mass interventions have implications on the use of condoms in casual relationships.

On the other hand, recent studies on new prevention strategies (circumcision, PrEP, and PEP) do not measure the impact of these interventions on the behavior of heterosexual men, particularly on those who are not involved in a serodiscordant relationship. However, the limited data available suggest the possibility of a relaxation in relation to condom use due to the feeling of protection promoted by medication or circumcision. Nonetheless, more studies are required to be conducted in order to corroborate these findings. Regarding testing, we found that men are tested less than women. And, although testing can be a good opportunity for early diagnosis, the characteristics of hegemonic masculinity go in the opposite direction to the care and prevention recommended by the testing strategy.

Treated as "equal", men are made (in)visible regarding the contradictions and vulnerabilities they face against the concrete exercise of masculinity. The inclusion in HIV / AIDS studies and interventions of the diversity that exists in the segment called "heterosexual men" is an important step to advancing in controlling the epidemic. That is, it is urgent to have a look at how crossing between categories such as gender, social class, race/ ethnicity, life stage, and age affect the behavior and preventive strategies adopted by the male population. If men can be considered the dominant pole regarding the female pole, it is possible to say a poor black man has different conditions of access to information, materials, and health services when compared to a white man with greater purchasing power. Still, all heterosexual men are vulnerable, to a greater or lesser extent, to the invisibility that occurs in the context of HIV prevention.

\section{REFERENCES}

1. Sabo D. Men's health studies: origins and trends. J Am Coll Health 2000; 49(3): 133-42.

2. Courtenay WH. Constructions of masculinity and their influence on men's well-being: a theory of gender and health. Soc Sci Med 2000; 50(10): 1385-401.

3. Arilha M. Políticas públicas de saúde, mulheres e DSTs/AIDS: reajustando o olhar. Coleção ABIA. Saúde Sexual e Reprodutiva, 4. Rio de Janeiro: Associação Brasileira Interdiciplinar de AIDS; 2001.
4. Couto MT, Gomes R. Homens, saúde e políticas públicas: a equidade de gênero em questão. Ciênc Saúde Coletiva 2012; 17(10): 2569-78.

5. Maia C, Guilhem D, Freitas D. Vulnerabilidade ao HIV/AIDS de pessoas heterossexuais casadas ou em união estável. Rev Saúde Pública 2008; 42(2): 242-8.

6. Silva CGM. O significado de fidelidade e as estratégias para prevenção da AIDS entre homens casados. Rev Saúde Pública 2002; 36(4 Suppl 0): 40-9. 
7. Garcia S, Souza FM. Vulnerabilidades ao HIV/aids no Contexto Brasileiro: iniquidades de gênero, raça e geração. Saúde Soc 2010; 19(Suppl 2): 9-20.

8. Guerriero ICZ. Masculinidades e prevenção do HIV. Bol Inst Saúde 2012; 14(1): 17-23.

9. Guerriero I, Ayres JRCM, Hearst N. Masculinidade e vulnerabilidade ao HIV de homens heterossexuais, São Paulo, SP. Rev Saúde Pública 2002; 36(4 Suppl 0): 50-60.

10. Connell RW. Masculinities. Berkeley: University of California Press; 2005.

11. Connell RW, Messerschmidt JW. Hegemonic masculinity: rethinking the concept. Gender Society 2005; 19(6): 829-59.

12. Dworkin SL, Hatcher AM, Colvin C, Peacock D. Impact of a gender-transformative HIV and antiviolence program on gender ideologies and masculinities in two rural, South African communities. Men Masc 2013; 16(2): 181-202.

13. Jewkes R, Nduna M, Jama Shai N, Dunkle K. Prospective study of rape perpetration by young South African men: incidence $\&$ risk factors. PLoS One 2012; 7(5): e38210.

14. Canetto SS, Cleary A. Men, masculinities and suicidal behaviour. Soc Sci Med 2012; 74(4): 461-5.

15. Meneghel SN, Gutierrez DMD, Silva RM, Grubits S, Hesler LZ, Ceccon RF. Suicídio de idosos sob a perspectiva de gênero. Ciênc Saúde Coletiva 2012; 17(8): 1983-92.

16. Minayo MCS, Meneghel SN, Cavalcante FG. Suicídio de homens idosos no Brasil. Ciênc Saúde Coletiva 2012; 17(10): 2665-74.

17. Noone JH, Stephens C. Men, masculine identities, and health care utilisation. Sociol Health Illn 2008; 30(5): 711-25.

18. Douglas FC, Greener J, van Teijlingen E, Ludbrook A. Services just for men? Insights from a national study of the Well Men Services Pilots. BMC Public Health 2013; 13(1): 425.

19. Marques Junior JS, Gomes R, Nascimento EF. Masculinidade hegemônica, vulnerabilidade e prevenção ao HIV/AIDS. Ciênc Saúde Coletiva 2012; 17(2): 511-20.

20. Ford NJ, Vieira EM, Villela WV. Beyond stereotypes of Brazilian male sexuality: qualitative and quantitative findings from São Paulo, Brazil. Cult Health Sex 2003; 5(1): 53-69.

21. Pires MRM, Balieiro CRB. Representações dos homens heterossexuais sobre DST/AIDS e o uso de preservativo nas relações sexuais. Saúde Transform Soc. 2012; 3(3): 89-104.
22. Brasil. Ministério da Saúde. Secretaria de Atenção à Saúde. Departamento de Ações Programáticas Estratégicas. Política Nacional de Atenção Integral à Saúde do Homem. Brasília: Ministério da Saúde; 2009.

23. Brasil. Ministério da Saúde. Plano de Enfrentamento da Epidemia de AIDS e das DST entre gays, HSH e travestis. Brasília: Ministério da Saúde; 2007. Disponível em: http:/ / bvsms.saude.gov.br/bvs/publicacoes/ plano_enfrentamento_epidemia_aids_hsh.pdf (Acessado em 28 de janeiro de 2014).

24. Brasil. Ministério da Saúde. Secretaria de Vigilância em Saúde. Departamento de Vigilância, Prevenção e Controle das DST e AIDS. Fundação Nacional de Saúde. Projeto AIDS-SUS Brasil. Programa Brasileiro para a Atenção à Saúde da População Indígena em HIV/AIDS e outras DST. Estrutura do Projeto para a População Indígena. Política Operacional do Banco Mundial 4.10. Brasília: Ministério da Saúde; 2009. Disponível em: http: / /www.aids.gov.br/sites/default/ files/BR_AIDS_SUS_IPPF_Portugues_Versao_Final. pdf (Acessado em: 28 de janeiro de 2014).

25. Miranda AE, Ribeiro D, Rezende EF, Pereira GFM, Pinto VM, Saraceni V. Associação de conhecimento sobre DST e grau de escolaridade entre conscritos em alistamento ao Exército Brasileiro. Brasil, 2007. Ciênc Saúde Coletiva 2013; 18(2): 489-97.

26. Szwarcwald CL, de Carvalho MF, Barbosa Júnior A, Barreira D, Speranza FA, de Castilho EA. Temporal trends of HIV-related risk behavior among Brazilian military conscripts, 1997-2002. Clinics (São Paulo). 2005; 60(5): 367-74.

27. Leal AF. No peito e na raça - a construção da vulnerabilidade de caminhoneiros: um estudo antropológico de políticas públicas para HIV/AIDS no sul do Brasil. Porto Alegre: Universidade Federal do Rio Grande do Sul; 2008. Disponível em: http:/ / hdl.handle.net/10183/15570 (Acessado em 14 de janeiro de 2014).

28. Frye V, Bonner S, Williams K, Henny K, Bond K, Lucy D, et al. Straight talk: HIV prevention for AfricanAmerican heterosexual men: theoretical bases and intervention design. AIDS Educ Prev 2012; 24(5): 389-407.

29. Galvão J. AIDS no Brasil: a agenda de construção de uma epidemia. Rio de Janeiro: Associação Brasileira Interdisciplinar de AIDS/Editora 34; 2000.

30. Figueroa-Perea JG. Algunos elementos para interpretar la presencia de los varones en los procesos de salud reproductiva. Cad Saúde Pública 1998; 14(Suppl 1): S87-96. 
31. Higgins JA, Hoffman S, Dworkin SL. Rethinking gender, heterosexual men, and women's vulnerability to HIV/AIDS. Am J Public Health 2010; 100(3): 435-45.

32. Pinheiro TF, Couto MT, Silva GSN. Homens e cuidado: construções de masculinidades na saúde pública brasileira. Psicol Conoc Soc 2012; 2(2): 177-95.

33. Gomes R, Nascimento EF. A produção do conhecimento da saúde pública sobre a relação homem-saúde: uma revisão bibliográfica. Cad Saúde Pública 2006; 22(5): 901-11.

34. Ayres JRC, Calazans GJ, Saletti Filho HC, França-Júnior I. O risco, vulnerabilidade e práticas de prevenção e promoção da saúde. In: Campos GWS, Minayo MCS, Akerman M, Junior MD, Carvalho YMd, editors. Tratado de Saúde Coletiva. São Paulo: Hucitec; 2006. p. 375-417.

35. Gomes R, Leal AF, Lima AM, Knauth DR, Moura EC, Silva GSN, et al. Avaliação das Ações Iniciais da Implantação da Política Nacional de Atenção Integral à Saúde do Homem (Relatório Final). Rio de Janeiro: IFF/Fiocruz; 2012.

36. Machin R, Couto MT, Silva GSN, Schraiber LB, Gomes R, Figueiredo WS, et al. Concepções de gênero, masculinidade e cuidados em saúde: estudo com profissionais de saúde da atenção primária. Ciênc Saúde Coletiva 2011; 16(11): 4503-12.

37. Figueiredo WS, Schraiber LB. Concepções de gênero de homens usuários e profissionais de saúde de serviços de atenção primária e os possíveis impactos na saúde da população masculina, São Paulo, Brasil. Ciênc Saúde Coletiva 2011; 16(Suppl 1): 935-44.

38. Couto MT, Pinheiro TF, Valença O, Machin R, Silva GSN, Gomes R, et al. O homem na atenção primária à saúde: discutindo (in)visibilidade a partir da perspectiva de gênero. Interface (Botucatu) 2010; 14(33): 257-70.

39. Townsend L, Mathews C, Zembe Y. A systematic review of behavioral interventions to prevent HIV infection and transmission among heterosexual, adult men in low-and middle-income countries. Prev Sci 2013; 14(1): 88-105.

40. Exner TM, Gardos PS, Seal DW, Ehrhardt AA. HIV sexual risk reduction interventions with heterosexual men: the forgotten group. AIDS Behav 1999; 3(4): 347-58.

41. Dowsett GW. Some considerations on sexuality and gender in the context of AIDS. Reprod Health Matters 2003; 11(22): 21-9.

42. Seal DW, Ehrhardt AA. HIV-prevention-related sexual health promotion for heterosexual men in the United States: pitfalls and recommendations. Arch Sex Behav 2004; 33(3): 211-22.
43. Rebello LEFS, Gomes R, Souza ACB. Homens e a prevenção da aids: análise da produção do conhecimento da área da saúde. Interface (Botucatu) 2011; 15(36): 67-78.

44. Pechansky F, Bassani DG, Diemen Lv, Kessler F, Leukefeld CG, Surratt HL, et al. Using thought mapping and structured stories to decrease HIV risk behaviors among cocaine injectors and crack smokers in the South of Brazil. Rev Bras Psiquiatr 2007; 29(3): 233-40.

45. Brasil. Ministério da Saúde. Secretaria de Vigilância em Saúde. Departamento de DST, AIDS e Hepatites Virais. Relatório de Progresso da Resposta Brasileira ao HIV/AIDS (2010-2011). Brasília: Ministério da Saúde; 2012 Disponível em: http: / /www.unaids.org. br/biblioteca/coletanea2012/links/ONU/ONU\%2011. pdf (Acessado em 28 de janeiro de 2014).

46. Brasil. Ministério da Saúde. Plano Integrado de Enfrentamento da Feminização da Epidemia de AIDS e outras DST. Revisado em 2011. Brasília: Ministério da Saúde, 2007. Disponível em: www.aids.gov.br/ feminizacao (Acessado em 20 de janeiro de 2014).

47. Lazzarotto AR, Santos VS, Reichert MT, Quevedo DM, Fossatti P, Santos GA, et al. Oficinas educativas sobre HIV/AIDS: uma proposta de intervenção para idosos. Rev Bras Geriatr Gerontol 2013; 16(4): 833-43.

48. Brasil. Ministério da Saúde. Secretaria de Vigilância em Saúde. Departamento de DST, AIDS e Hepatites Virais. Manual técnico para o diagnóstico da infecção pelo HIV. Brasília: Ministério da Saúde; 2013 Disponível em: http:/ / www.sbpc.org.br/upload/conteudo/ manual_tecnico_hiv_2013.pdf (Acessado em 20 de janeiro de 2014).

49. Soares PS, Brandão ER. O aconselhamento e a testagem anti-HIV como estratégia preventiva: uma revisão da literatura internacional, 1999-2011. Saúde Soc 2012; 21(4): 940-53.

50. Joint United Nations Programme on HIV/AIDS (UNAIDS). Global report: UNAIDS report on the global AIDS epidemic 2013. Geneva: UNAIDS; 2013.

51. França Junior I, Calazans G, Zucchi EM. Mudanças no âmbito da testagem anti-HIV no Brasil entre 1998 e 2005. Rev Saúde Pública 2008; 42(Suppl 1): 84-97.

52. Soares PS, Brandão ER. O aconselhamento e a testagem anti-HIV como estratégia preventiva: uma revisão da literatura internacional, 1999-2011. Saúde Soc 2012; 21(4): 940-53.

53. Pascom ARP, Szwarcwald CL. Sex inequalities in HIV-related practices in the Brazilian population aged 15 to 64 years old, 2008. Cad Saúde Pública. 2011; 27(Suppl 1): s27-35. 
54. UNAIDS/WHO/SACEMA Expert Group on Modelling the Impact and Cost of Male Circumcision for HIV Prevention. Male circumcision for HIV prevention in high HIV prevalence settings: what can mathematical modelling contribute to informed decision making? PLoS Med 2009; 6(9): e1000109.

55. Newer approaches to HIV prevention. Lancet 2007; 369(9562): 615 .

56. Mills E, Cooper C, Anema A, Guyatt G. Male circumcision for the prevention of heterosexually acquired HIV infection: a meta-analysis of randomized trials involving 11050 men. HIV Med 2008; 9(6): 332-5.

57. Gray RH, Kigozi G, Serwadda D, Makumbi F, Watya S, Nalugoda F, et al. Male circumcision for HIV prevention in men in Rakai, Uganda: a randomised trial. Lancet 2007; 369(9562): 657-66.
58. Ware NC, Wyatt MA, Haberer JE, Baeten JM, Kintu A, Psaros C, et al. What's love got to do with it? Explaining adherence to oral antiretroviral pre-exposure prophylaxis for HIV-serodiscordant couples. J Acquir Immune Defic Syndr 2012; 59(5): 463-8.

59. Baeten J, Celum C. Systemic and topical drugs for the prevention of HIV infection: antiretroviral preexposure prophylaxis. Annu Rev Med 2013; 64(1): 219-32.

60. Baeten JM, Donnell D, Ndase P, Mugo NR, Campbell JD, Wangisi J, et al. Antiretroviral prophylaxis for HIV Prevention in heterosexual men and women. N Engl J Med 2012; 367(5): 399-410.

Received on: 01/05/2014

Final version presented on: 08/11/2014

Accepted on: 09/04/2014 